\title{
Recenzja
}

\section{Małgorzata Niewiadomska-Cudak, Wybory samorzadowe w Łodzi w latach 1990-2006, Wydawnictwo Adam Marszałek, Toruń 2011, ss. 279}

Konstytucja Rzeczypospolitej Polskiej nie przesądza jednoznacznie ostrukturze samorządu terytorialnego, pozostawiając te kwestie regulacji ustawowej. W art. 164 przewiduje jednak wieloszczeblowość tego samorządu, wprowadzając obowiązek istnienia co najmniej dwóch jego szczebli. Wprost stanowi, że jednym ze szczebli obligatoryjnych ma być szczebel gminny, drugim - szczebel regionalny (nie używając na jego określenie konkretnej nazwy), przy czym gminę określono jako jednostkę o charakterze podstawowym, przyznając jej prawo do wykonywania wszystkich zadań samorządu terytorialnego, niezastrzeżonych dla innych jego jednostek. Jednocześnie w art. 164 ust. 2 ustrojodawca przewidział możliwość tworzenia innych jeszcze - poza dwoma obligatoryjnymi - szczebli samorządu lokalnego lub regionalnego. Ustawodawca natomiast zdecydował się na ustanowienie w Polsce trzech szczebli samorządu; obok mających umocowanie konstytucyjne gmin istnieją powiaty i województwa samorządowe. Co więcej, ustrojodawca przyznaje jednostkom samorządu terytorialnego osobowość prawną, czyni je podmiotami prawa własności i innych praw majątkowych, które to cechy składają się łącznie na samodzielność jednostek samorządu.

Ponieważ podstawowym uprawnieniem wspólnoty samorządowej jest uczestniczenie w sprawowaniu władzy publicznej, w tym wykonywanie istotnej części zadań publicznych, dlatego powszechne wybory organów samorządu terytorialnego pełnią niezwykle ważną rolę. Istnienie samorządu, którego organy są kształtowane zgodnie z wolą członków wspólnoty lokalnej jest wyrazem zasady decentralizacji władzy publicznej. Co więcej: pochodzący z wyborów powszechnych samorząd terytorialny powinien mieć prawo do rozstrzygania wszelkich spraw, jakie tylko jest w stanie wykonywać.

Należy więc w pierwszej kolejności podnieść, że Autorka, opisując wybory samorządowe w Łodzi na przełomie 16 lat, podjęła temat niezwykle ważny z punktu widzenia funkcjonowania zarówno państwa, jak i wspólnoty lokal- 
nej. Pozytywna ocena wyboru tematu jest uzasadniona zarówno z perspektywy globalnej - posługując się przykładem Łodzi, Autorka opisuje ogólne zasady i zmiany w samorządowym prawie wyborczym, a także odnotowuje mechanizmy wyborcze charakterystyczne także dla innych jednostek samorządu terytorialnego, jak i lokalnej - dotychczas bowiem brakowało opracowania, które przekrojowo analizowałoby przebieg i rezultaty wyborów w Łodzi, będącej jednym z największych miast polskich. Należy ocenić, że upływ 16 lat od pierwszych demokratycznych wyborów samorządowych daje odpowiednią perspektywę porównawczą i pozwala z powodzeniem podjąć ten temat.

Autorka - jak sama wskazała we Wstępie - postawiła sobie za cel dokonać oceny wpływu wyborów samorządowych na lokalną scenę polityczną poprzez analizę uczestników wyborów, wpływu ordynacji wyborczej i przebiegu kampanii oraz wyników wyborów. Sformułowała jednocześnie na użytek prowadzonych badań cztery hipotezy. Pierwsza z nich zakłada, że sukces wyborczy w Łodzi w badanym okresie odnosiły partie, które miały swoje przedstawicielstwo w Sejmie. Druga z kolei przewiduje, że na wyborcze działania partii w Łodzi miały wpływ zmieniające się regulacje samorządowych ordynacji wyborczych. Trzecia sprowadza się do założenia, że decydującym czynnikiem wpływającym na wynik wyborczy była efektywność działań wyborczych, która przeszła w badanym okresie ewolucję od „amatorskich poczynań” do korzystania z koncepcji i metod marketingu politycznego. Czwarta hipoteza wreszcie głosi, że sukces w wyborach odnosiły partie zawierające koalicje wyborcze, które to później przekształcały się w koalicje gabinetowe.

Dla weryfikacji tak sformułowanych hipotez analizę tematu pracy Autorka podzieliła na sześć rozdziałów. W pierwszym zajęła się ogólną analizą systemu wyborczego do parlamentu i organów samorządowych III Rzeczypospolitej Polskiej. Rozdziały II, III, IV, V i VI są z kolei poświęcone poszczególnym elekcjom samorządowym, przeprowadzanym odpowiednio w latach: 1990, 1994, 1998, 2002 i 2006. Taki układ pracy z pewnością systematyzuje prowadzoną analizę, pozwalając jednocześnie na prawidłowe zastosowanie wybranych przez Autorkę metod badawczych, tj. przede wszystkim metody komparatystycznej. Umożliwia jednocześnie czytelnikowi podążanie za kolejnymi zmianami w samorządowym prawie wyborczym i w przebiegu poszczególnych kampanii wyborczych. 
W każdym z rozdziałów odnoszących się do poszczególnych elekcji Autorka wprowadziła identyczną systematykę wewnętrzną, wyróżniając podrozdziały: ordynacja wyborcza, uczestnicy wyborów samorządowych, kampania wyborcza, rezultaty i skutki wyborów, co także porządkuje rozważania i pozwala na szybkie dokonanie porównań w odniesieniu do poszczególnych zagadnień wyborczych na przestrzeni lat. Można zgłosić jedynie jedną, bardzo szczegółową uwagę, a to taką, że tytułując jeden z podrozdziałów: „Rezultaty i skutki wyborów”, Autorka nie wyjaśniła, co rozumie przez „rezultaty”, a co przez „skutki”. Należy pewnie domniemywać, że „rezultaty” to dla Autorki po prostu wyniki wyborów w rozumieniu prawa wyborczego, skutki zaś dotyczą wpływu wyników wyborów na funkcjonowanie organów samorządu i lokalnej sceny politycznej. Wydaje się więc, że bardziej prawidłowe byłoby posłużenie się właśnie terminem „wyniki wyborów” albo choćby wyjaśnienie, co dla Autorki użyte określenia oznaczają.

Przechodząc do merytorycznej analizy poszczególnych rozdziałów, podkreślić należy, że pierwszy z nich ma charakter wprowadzający i przybliża czytelnikowi system wyborczy do parlamentu i organów samorządowych w Polsce. Autorka opisuje w nim funkcje wyborów, typy i elementy systemów wyborczych oraz analizuje wpływ ewolucji systemu wyborczego na zmiany regulacji dotyczących partii politycznych. Rozważania te z pewnością są potrzebne. Uzasadnione jest także przybliżenie przez Autorkę reguł rządzących wyborami parlamentarnymi (wbrew ogólnemu wskazaniu w tytule rozdziału rozważania koncentrują się na wyborach do Sejmu, raczej z pominięciem Senatu), analizując bowiem w dalszych rozdziałach poszczególne elekcje samorządowe, opisuje wpływ, jakie mogły na nie mieć poprzedzające wybory do parlamentu.

Lektura rozdziału pierwszego nasuwa jednak także pewne uwagi krytyczne. Po pierwsze, wydaje się, że Autorka nie wykorzystała w pełni niezbędnej literatury. Opisując zasady rządzące wyborami oraz funkcje wyborów, pominęła bowiem takie opracowania monograficzne jak: Standardy prawne wolnych wyborów parlamentarnych autorstwa Grzegorza Kryszenia, Zasada powszechności w prawie wyborczym: zagadnienia teorii i praktyki Krzysztofa Skotnickiego czy też publikacje tego Autora dotyczące funkcji wyborów, oparła zaś prowadzone rozważania raczej na opracowaniach ogólnych, często encyklopedycznych i słownikowych. Taka podstawa piśmienni- 
cza, wobec istnienia wielu opracowań szczegółowych odnoszących się do zasad i funkcji wyborów, wydaje się niewystarczająca.

Druga uwaga ma charakter merytoryczny. Otóż nie sposób podzielić wyrażonego przez Autorkę po raz pierwszy na s. 26, a później wielokrotnie powtarzanego poglądu, jakoby w Polsce w wyborach do rad gmin funkcjonował system mieszany. Autorka swoje stanowisko uzasadnia tym, że w gminach liczących mniej mieszkańców stosowany jest system większościowy, w większych zaś - system proporcjonalny. To jednak - należy podkreślić - nie daje podstaw do uznania, że mamy do czynienia z systemem mieszanym. System mieszany polega bowiem na połączeniu określonych cech systemu większościowego i proporcjonalnego w wyborach do jednego organu. Nie można więc przyjąć, że mieszanym jest system wyborczy wówczas, gdy do części rad gmin wybory przebiegają w całości w oparciu o reguły systemu większościowego, do innych zaś - w całości o reguły systemu proporcjonalnego. Oznacza to jedynie tyle, że w mniejszych gminach w wyborach do rad obowiązuje system większościowy, w większych - proporcjonalny i nie można na tej podstawie ogólnie określać wyborów do rad gmin mianem mieszanych.

Na s. 17, definiując prawo wyborcze jako prawo polityczne, Autorka jednoznacznie traktuje je jako prawo przysługujące jedynie obywatelom. Wydaje się, że tak kategoryczne stwierdzenie jest nieuzasadnione, w szczególności w odniesieniu do wyborów samorządowych. Należy bowiem pamiętać - na co zresztą Autorka zwraca uwagę w dalszej części pracy - że prawo udziału w tych wyborach mają także osoby niebędące obywatelami polskimi, mające natomiast obywatelstwo Unii Europejskiej i mieszkające w Polsce.

Należy wreszcie odnotować, że opisując przymiotniki wyborcze, Autorka niepoprawnie odwołuje się do zasady tajności, pisząc o niej jako o zasadzie „tajności wyborów” (np. s. 37 oraz s. 122). Tajność polega na zagwarantowaniu, iż nikt poza wyborcą nie będzie miał możliwości poznania treści jego głosu. Tak rozumiana tajność gwarantuje nieskrępowane oddanie głosu przez wyborcę, w sposób zgodny wyłącznie z jego wolą. Tajność nie odnosi się więc do całego procesu wyborczego - nie jest przecież tajne udzielenie poparcia określonej liście kandydatów, bo następuje poprzez złożenie pod nią podpisu, nie jest też tajny sam fakt zagłosowania, gdyż wyborca przed otrzymaniem karty do głosowania podpisuje się w spisie wyborców, ani tym bardziej uczestniczenie $\mathrm{w}$ wyborach $\mathrm{w}$ charakterze kandydata na posła - a je- 
dynie do jednego etapu procedury wyborczej, tj. do głosowania. Nie można więc mówić o „tajności wyborów”, a jedynie o „tajności głosowania”.

Przechodząc do oceny rozważań prowadzonych w następnych rozdziałach, tych opisujących poszczególne elekcje, należy przede wszystkim podkreślić ich duży walor poznawczy. Autorka szczegółowo i wszechstronnie opisuje kolejne wybory samorządowe: przedstawia przepisy prawa wyborczego, które obowiązywały w datach kolejnych elekcji, lokalną scenę polityczną i determinanty ją kształtujące, przebieg kampanii wyborczej, analizuje wyniki wyborów i ich wpływ na funkcjonowanie organów samorządu oraz ugrupowań politycznych. Sposób prowadzenia analizy czyni ją ciekawą dla czytelnika. Pozwala także odnotować najważniejsze nurty ewolucji wyborów samorządowych w Łodzi. Ta część rozważań napisana jest zrozumiałym językiem, Autorka prawidłowo wyjaśnia podejmowane wątki, zarówno od strony analizy teoretyczno-naukowej, jak i ilustrując je interesującymi przykładami z praktyki.

Tym niemniej również i do tej części opracowania trzeba zgłosić kilka uwag polemicznych. Po pierwsze, należy zastanowić się, czy nie byłoby wskazane przeprowadzić choćby skrótowej analizy także wyborów do Sejmiku Województwa Łódzkiego w okręgach wytyczonych na obszarze miasta. Analiza taka mogłaby stanowić ciekawy materiał porównawczy, chociażby w zakresie przebiegu kampanii wyborczej oraz wyników wyborów do Rady Miejskiej w Łodzi. Jeżeli jednak Autorka zdecydowała, że takich rozważań prowadzić nie będzie, to wydaje się, że wobec ogólnego tematu książki Wybory samorzadowe w Łodzi powinna wyraźnie zaznaczyć swoją decyzję i ją uzasadnić. Tym bardziej że przybliżając czytelnikowi przebieg kampanii i wyniki poszczególnych wyborów samorządowych w całym kraju, nie pomija tych na poziomie województwa.

Wydaje się także, że opisując wyniki wyborów do Rady Miejskiej z 1998 r., warto by było odnotować, że mandaty zdobyła wówczas duża grupa młodych osób, startujących z list SLD. Było to o tyle interesujące, że byli to kandydaci zajmujący na listach dalsze miejsca, którzy w wyborach zdobywali zazwyczaj drugie wyniki na swoich listach, uzyskując często wielokrotnie więcej głosów aniżeli ich starsi koledzy. Z punktu widzenia analizy politologicznej ciekawe więc byłoby zbadanie przyczyn tego zjawiska i ich skutków dla funkcjonowania organu stanowiącego. 
Także w tej części pracy należy, niestety, odnotować kilka nieścisłości. Przede wszystkim nie sposób zgodzić się ze sformułowaną na s. 162 definicją większości bezwzględnej jako „50\% plus 1” głos, większość tę należy bowiem rozumieć jako więcej niż połowę oddanych głosów. Po drugie, szkoda, że Autorka nie sięgnęła do interesujących artykułów opisujących wybory samorządowe w Łodzi, np. przy opisywaniu skutków blokowania list w wyborach w 2006 r. Autorka pominęła bardzo ciekawy artykuł Macieja Rakowskiego pt. Blokowanie list $w$ wyborach samorzadowych - nowelizacja ordynacji wyborczej i jej skutki na przykładzie wyborów do rad miast wojewódzkich („Studia Wyborcze” t. III, 2007), w którym autor bardzo interesująco opisuje skutki wprowadzonej wówczas nowelizacji, m.in. także dla Łodzi, czy artykuł Atrakcyjność wyborcza kandydatów na radnych w wyborach samorządowych Grzegorza Matuszaka, także poruszający tematykę wyborów samorządowych w Łodzi z tego samego zeszytu "Studiów Wyborczych”.

$\mathrm{Na}$ koniec wreszcie odnotować należy pewne niedociągnięcia, głównie językowe, które - choć niewielkie - powinny być wyeliminowane przed publikacją. Np. kilkakrotnie w pracy używa się słowa „prelegent” w sposób nieodpowiadający znaczeniu tego słowa, myląc je zapewne ze słowem „pretendent” (np. s. 205 i 211), wielokrotnie powtarza się w bierniku rodzaju żeńskiego forma "tą" w miejsce „tę". Trzeba też zaznaczyć, że niezrozumiała dla czytelnika, a na pewno nieodpowiadająca opisowi, jest tabelka na s. 95-96.

Tym niemniej przywołane usterki nie przekreślają ogólnie pozytywnej oceny opracowania. Jak już zaznaczono, jest ono wyjątkowe, dotyczy bowiem zagadnień, które dotychczas nie doczekały się opracowania całościowego. Książka jest ciekawa, pisana żywym, zrozumiałym językiem. Tym samym jest godna polecenia nie tylko osobom naukowo zajmującym się tematyką wyborczą i samorządową, ale wszystkim tym, którzy są zainteresowani historią Łodzi ostatnich dwudziestu lat.

Anna Rakowska (Uniwersytet Łódzki) 